\title{
Pengaruh Profitabilitas, Lagged Dividend, Size, dan Leverage pada Kebijakan Dividen
}

\author{
Selaristi Izdihar ${ }^{1}$, Suhendro ${ }^{2}$, Rosa Nikmatul Fajri ${ }^{3}$ \\ 1,2,3 Universitas Islam Batik, JL. KH. Agus Salim No. 10, Surakarta, Indonesia \\ Correspondence email: selaristiizdihar814@gmail.com
}

\begin{abstract}
Abstrak. Penelitian ini bertujuan untuk menguji dan menganlisis pengaruh profitabilitas, lagged dividend, size, dan leverage pada kebijakan dividen. Populasi dalam penelitiann ini adalah perusahaan sektor industri barang konsumsi yang terdaftar di Bursa Efek Indonesia (BEI) tahun 2016-2018. Jenis penelitian ini adalah penelitian kuantitatif. Pengambilan sampel dengan teknik purposive sampling menghasilkan 19 perusahaan sektor industri barang konsumsi tahun 2016-2018 sesuai kriteria yang ditentukan, sehingga diperoleh 57 data penelitian. Penelitian ini menggunakan analisis regresi linear berganda dengan program IMB SPSS versi 23. Hasil penelitian ini disimpulkan bahwa profitabilitas dan lagged dividen berpengaruh pada kebijakan dividen. Sedangkan size dan leverage tidak berpengaruh pada kebijakan dividen.
\end{abstract}

Kata Kunci: Profitabilitas; Lagged Dividend; Size; Leverage; Kebijakan Dividend

Abstract. This study aims to examine and analyze the effect of profitability, lagged dividends, size, and leverage on dividend policy. The population in this study are companies in the consumer goods industry sector which are listed on the Indonesia Stock Exchange (BEI) in 2016-2018. This type of research is quantitative research. Sampling with purposive sampling technique resulted in 19 companies in the consumer goods industry sector in 2016-2018 according to the specified criteria, in order to obtain 57 research data. This study uses multiple linear regression analysis with the SPSS version 23. IMB program. The results of this study concluded that profitability and lagged dividends affect the dividend policy. While size and leverage have no effect on dividend policy.

Keywords: Profitability; Lagged Dividend; Size; Leverage; Dividend Policy

\section{PENDAHULUAN}

Kebijakan dividen yaitu keputusan perusahaan apakah laba akan dibagikan kepada pemegang saham atau menjadi laba ditahan sebagi pembiayaan investasi untuk masa yang akan datang (Sartono, 2014). Kebijakan dividen adalah faktor penting yang harus dipikirkan perusahaan dalam mengelola perusahaan karena memiliki pengaruh terhadap perusahaan, pemegang saham, kreditur dan masyarakat. Kebijakan dividen mempengaruhi perusahaan karena akan mengurangi kas perusahaan sehingga dana untuk kegiatan operasional dan investasi akan berkurang. Perencanaan kebijakan dividen yang tepat bagi perusahaan dapat mencegah ketidakpuasan pasar dan melindungi harga saham perusahaan. Kebijakan dividen mempengaruhi pemegang saham, karena mereka akan melihat kebijakan dividen sebagai indikator yang tepat untuk melihat laba yang diharapkan dari perusahaan. Bagi pemegang saham, dividen merupakan bentuk pengembalian investasi yang mereka tanamkan. Jika perusahaan dapat meningkatkan pembayaran dividen, maka menunjukkan laba perusahaan meningkat dimasa yang akan datang, sehingga akan menarik minat investor untuk berinvestasi. Bagi kreditur, dividen dapat menunjukkan bahwa perusahaan mampu membayar bunga dan pinjaman sehingga meningkatkan kepercayaan kreditur. Bagi masyarakat yaitu dapat memberikan gambaran bahwa perusahaan yang mampu membayar dividen adalah perusahaan yang memiliki kredibilitas baik (Thirtayatra dan Arliando, 2008).

Setiap perusahaan harus mampu mempertahankan perusahaannya serta mengembangkan bisnis untuk mendapat laba. Dividen merupakan laba bersih perusahaan yang dibagikan kepada pemegang saham berdasarkan kepemilikan saham. Perusahaan akan mempertimbangkan laba yang diperoleh, apakah akan ditahan atau dibagikan kepada pemegang saham yang disebut kebijakan dividen (Sartono, 2014). Namun perusahaan sering menghadapi permasalahan penentuan kebijakan pembayaran dividen, apakah akan membagikan laba kepada pemegang saham sebagai dividen ataumenahan dalam bentuk laba yang ditahan untuk pembiayaan investasi di masa yang akan datang.

Kebijakan dividen perusahaan digambarkan dengan Dividend Payout Ratio (DPR). Menurut Riyanto (2008) DPR merupakan presentase dari pendapatan yang akan dibayarkan kepada para pemegang saham sebagai dividen. Semakin tinggi DPR maka akan menguntungkan para pemegang saham tetapi akan memperlemah keuangan internal perusahaan karena memperkecil laba ditahan. Sebaliknya menurut Parica et al (2013) jika DPR rendah maka akan merugikan pemegang saham tetapi keuangan internal perusahaan akan menguat.

Menurut Wiagustini (2014) profitabilitas adalah kemampuan perusahaan memperoleh laba yang digunakan sebagai pengukur tingkat efektivitas dalam 
perusahaan. Profitabilitas dalam penelitian ini diukur dengan Return on Assets (ROA) yaitu tingkat keuntungan bersih yang diperoleh perusahaan dalam menjalankan operasional perusahaan. Semakin besar kemampuan perusahaan dalam menghasilkan laba maka semakin besar dividen yang akan dibagikan kepada pemegang saham.

Lagged dividend adalah dividen yang dibayarkan satu tahun sebelum tahun yang dipertimbangkan. Lagged dividend menunjukkan keinginan dari managemen perusahaan untuk mengikuti kebijakan dividen stabil. Lintner (1956) yang mensurvei 28 manajer di Amerika Serikat dan menyimpulkan bahwa dividen masa lalu adalah faktor kunci yang mempengaruhi kebijakan dividen. Lagged dividend dalam penelitian ini diukur dengan Dividen pershare tr-1. $_{\text {. Pembagian dividen }}$ tahun sebelumnya (lagged dividend) yang menunjukkan peningkatan adalah bukti bahwa perusahaan memiliki prospek masa depan yang baik. Hal ini sesuai dengan signaling theory yaitu apabila lagged dividend mengalami kenaikan maka akan mendorong perusahaan untuk meningkatkan pembagian dividen, dan perusahaan berusaha semaksimal mungkin memberikan sinyal kepada investor bahwa perusahaan mampu menghasilkan laba yang baik tiap tahunnya melalui pembagian dividen.

Martini et al (2014) menyatakan bahwa size atau ukuran perusahaan adalah sebagai penilaian seberapa besar atau kecil perusahaan dilihat dari aset, jumlah penjualan, rata-rata total penjualan dan total aset ratarata. Size pada penelitian ini diukur dengan logaritma dari total aset, untuk dapat mengukur jumlah nilai kekayaan yang dimiliki suatu perusahaan. Perusahaan dengan ukuran yang lebih besar memiliki arus kas operasi yang lebih stabil sehingga peluangnya membagikan dividen lebih besar.

Menurut Fahmi (2011) rasio leverage yaitu untuk mengukur seberapa besar perusahaan dibiayai dengan utang. Dalam penelitian ini leverage diukur menggunakan Debt to Equity Ratio (DER). Perusahaan yang memiliki rasio utang lebih besar seharusnya membagikan dividen lebih kecil karena laba yang diperoleh digunakan untuk melunasi kewajiban. Leverage yang semakin tinggi akan menyebabkan kebijakan dividen semakinmenurun, begitu pula sebaliknya. Berkurangnya hutang yang dibayarkan maka laba yang didapatkan semakin meningkat.

Penelitian ini dilakukan pada perusahaan sektor industri barang konsumsi yang terdaftar di Bursa Efek Indonesia. Industri barang konsumsi merupakan salah satu sektor industri yang cukup menarik, karena produk barang konsumsi selalu dibutuhkan dalam kehidupan manusia. Sektor industri barang konsumsi merupakan sektor penyumbang utama dalam pertumbuhan ekonomi Indonesia. Sektor industri barang konsumsi yaitu salah satu sektor yang mempunyai peranan penting dalam memicu pertumbuhan ekonomi Indonesia. Industri barang konsumsi ini terdiri dari lima subsektor yaitu industri makanan dan minuman, industri kosmetik dan keperluan rumah tangga, industri rokok, industri farmasi, industri peralatan rumah tangga, dan industri lainnya.

Berdasarkan latar belakang dari studi empiris penelitian terdahulu yang kontradiktif yaitu adanya perbedaan atau tidak konsistennya hasil penelitian/gap research dari penelitian yang dilakukan oleh Silaban dan Purnawati (2016), bahwa profitabilitas berpengaruh positif dan signifikan terhadap kebijakan dividen. Berbeda dengan Sari dan Sudjarni (2015), bahwa profitabilitas tidak berpengaruh terhadap kebijakan diividen. Gap research dari penelitian yang dilakukan oleh Damayanti, Marwati, dan Widayanti (2017), bahwa lagged dividend berpengaruh positif terhadap DPR. Berbeda dengan Benlemlih (2018), bahwa lagged dividend berpengaruh negatif signifikan terhadap $D P R$. Gap research dari penelitian yang dilakukan oleh Dhuhri dan Diantimala (2018) bahwa size berpengaruh positif terhadap kebijakan dividen. Berbeda dengan penelitian Parsian dan Shams (2013), bahwa size tidak berpengaruh signifikan terhadap kebijakan dividen. Gap research dari penelitian yang dilakukan oleh Rehman dan Takumi (2012), bahwa leverage menunjukkan hubungan positif dan signifikan terhadap kebijakan dividen. Berbeda dengan penelitian Ramadhani, Andreas, dan Desmiyawati (2015), bahwa leverage tidak berpengaruh terhadap kebijakan dividen, maka peneliti tertarik untuk melakukan penelitian kembali pengaruh profitabilitas, lagged dividend, size, dan leverage pada kebijakan dividen pada perusahaan sektor industri barang konsumsi yang terdaftar di Bursa Efek Indonesia (BEI) tahun 2016-2018.

Signaling theory atau teori sinyal adalah teori yang mengatakan bahwa investor menganggap perubahan dividen sebagai sinyal dari perkiraan pendapatan perusahaan (Brigham dan Houston, 2014). Teori sinyal menjelaskan bagaimana perusahaan mengeluarkan sinyal berupa informasi yang dapat menjelaskan keadaan perusahaan tersebut lebih baik dibandingkan dengan perusahaan lainnya. Sinyal yang dikeluarkan perusahaan membantu investor dalam menilai suatu perusahaan. Salah satu informasi yang dikeluarkan perusahaan berupa informasi keuangan yang menjelaskan kinerja keuangan perusahaan tersebut yang diukur dengan menghitung berbagai rasio keuangan. Dalam teori sinyal menyatakan tindakan yang diambil perusahaan dapat memberikan petunjuk para investor untuk memandang prospek perusahaan dimasa yang akan datang (Brigham dan Houston, 2014). Sinyal tersebut dapat memberikan informasi yang menyatakan perusahaan dapat lebih baik daripada perusahaan lain. Setiap perusahaan akan berusaha untuk memaksimalkan kemakmuran investor dengan memberikan dividen semaksimal mungkin. Sejalan dengan teori signaling effect bahwa dividen mempunyai kandungan informasi mengenai prospek perusahaan dimasa yang akan datang. 
Semakin besar Dividend Payout Ratio (DPR), artinya semakin besar pula keuntungan yang dapat diperoleh pemegang saham.

\section{Kebijakan Dividen}

Kebijakan dividen adalah keputusan apakah laba akan dibagikan kepada investor sebagai deviden atau akan ditahan sebagai pembiayaan investasi dimasa akan datang (Hakim, 2011). Kebijakan dividen yang baik yaitu jika dikatakan sebagai perusahaan yang menguntungkan dan mampu membayarkan dividennya (Sari dan Sudjarni, 2015). Kebijakan dividen diukur dengan Dividend Payout Ratio (DPR), yaitu perbandingan antara dividen yang dibayarkan dengan laba bersih. DPR sangat berkaitan dengan kinerja keuangan perusahaan. Bila kinerja keuangan perusahaan bagus maka perusahaan tersebut akan mampu menetapkan besarnya DPR sesuai dengan harapan pemegang saham (Marlina dan Danica, 2009).

\section{Profitabilitas}

Menurut Kasmir (2016) rasio profitabilitas yaitu rasio untuk menilai kemampuan perusahaan dalam mencari keuntungan. Rasio profitabilitas diukur menggunakan rasio return on assets (ROA). Rasio ini juga memberikan ukuran tingkat efektivitas manajemen suatu perusahaan. Salah satu yang menjadi faktor penentuan pembayaran dividen yang menjadi acuan adalah laba yang diperoleh perusahaan. Laba yang diperoleh perusahaan tersebut digunakan untuk membayar dividen kepada pemegang saham. Jika laba yang diperoleh kecil, maka dividen yang akan dibagikan juga kecil. Semakin besar laba yang diperoleh akan mempengaruhi pembayaran dividen yang dibagikan kepada pemegang saham. Investor yang menanamkan investasinya pada suatu perusahaan bertujuan untuk mendapatkan return. Semakin tinggi profit yang dihasilkan oleh perusahaan, maka semakin besar harapan pemegang saham untuk mendapatkan return yang tinggi dari perusahaan.

\section{Lagged Dividend}

Lintner (1956) yang mensurvei 28 manajer di Amerika Serikat dan menyimpulkan bahwa dividen masa lalu adalah faktor kunci yang mempengaruhi kebijakan dividen. Lagged dividend adalah dividen yang dibayarkan satu tahun sebelum tahun yang dipertimbangkan. Lagged dividend diukur dengan Dividen per share $_{t-1}$. Lagged dividend menunjukkan keinginan dari managemen perusahaan untuk mengikuti kebijakan dividen stabil. Kebijakan ini kemungkinan disebabkan oleh asumsi bahwa investor melihat kenaikan dividen sebagai suatu tanda baik bahwa perusahaan memiliki prospek yang baik. Perusahaan yang tidak merubah kebijakan dividennya secara cepat, maka pembayaran dividen pada tahun sebelumnya dapat dipertimbangkan sebagai ukuran untuk menentukan kebijakan dividen tahun berjalan. Jika lagged dividend bernilai positif maka kebijakan dividen pada perusahaan tersebut stabil, begitu juga dengan sebaliknya.

\section{Size}

Ukuran perusahaan atau size merupakan ukuran besarnya aset yang dimiliki perusahaan (Seftianne dan Handayani, 2011). Ukuran perusahaan dapat dinyatakan dengan total aktiva atau total penjualan bersih yang diukur dengan menggunakan logaritma dari total asset.Semakin besar aktiva atau penjualan maka semakin besar pula ukuran perusahaan. Pada umumnya semakin besar suatu perusahaan maka akan semakin besar pula aktivitasnya. Ukuran perusahaan juga dapat dikaitkan dengan besarnya kekayaan yang dimiliki oleh perusahaan. Sehingga ukuran perusahaan mempunyai pengaruh terhadap pembagian dividen. Semakin besar ukuran perusahaan maka semakin besar kemampuan perusahaan dalam membagikan dividen kepada pemegang saham.

\section{Leverage}

Menurut Brigham dan Houston (2014), leverage adalah rasio yang mengukur sejauh mana perusahaan menggunakan pendanaan melalui utang. Rasio leverage digunakan untuk mengetahui apakah perusahaan sudah menggunakan pinjaman modal yang diberikan dengan baik dan menguntungkan (Munawir, 2010). Dalam penelitian ini leverage diukur dengan DER, yaitu rasio leverage yang menunjukkan perbandingan total hutang terhadap ekuitas yang dimiliki perusahaan. Semakin besar leverage keuangan yang dimilki oleh perusahaan, maka resiko perusahaan juga besar sehingga semakin kecil kemungkinan membayar kewajibannya. Semakin tinggi rasio utang, maka semakin ketatnya perusahaan terhadap perjanjian utang. Kaitannya dengan pembayaran dividen, maka semakin tinggi rasio utang, pembayaran dividen akan semakin kecil.

\section{Penelitian Sebelumnya}

Penelitian yang dilakukan oleh Welas dan Nugroho (2019), menunjukkan bahwa variabel ROA tidak berpengaruh terhadap DPR. Berbeda dengan penelitian oleh Dewi dan Sedana (2018), menunjukkan bahwa profitabilitas berpengaruh positif terhadap kebijakan dividen.

Penelitian yang dilakukan oleh Widyawati dan Indriani (2019), menunjukkan bahwa lagged dividend berpengaruh positif terhadap DPR. Berbeda dengan penelitian oleh Jabbouri (2016), menunjukkan tidak ada hubungan signifikan dividen tahun lalu dengan kebijakan dividen.

Penelitian yang dilakukan oleh Madyoningrum (2019), menunjukkan bahwa firm size berpengaruh terhadap kebijakan dividen. Berbeda dengan penelitian oleh Rosmawati (2019), menunjukkan bahwa firm size tidak berpengaruh pada kebijakan dividen. 
Penelitian yang dilakukan oleh Shaheen dan Ullah (2018), menunjukkan bahwa leverage memiliki pengaruh negatif terhadap kebijakan dividen. Berbeda dengan penelitian oleh Riastini dan Pradnyani (2017), menunjukkan bahwa rasio keuangan leverage berpengaruh positif dan signifikan terhadap kebijakan dividen.

Dengan menguji pengaruh profitabilitas, lagged dividend, size, dan leverage pada kebijakan dividen, maka hipotesis yang diajukan dalam penelitian ini adalah:

H1 : Profitabilitas berpengaruh pada kebijakan dividen

$\mathrm{H} 2 \quad$ : Lagged dividend berpengaruh pada kebijakan dividen

H3 : Size berpengaruh pada kebijakan dividen

$\mathrm{H} 4 \quad$ : Leverage berpengaruh pada kebijakan dividen

\section{METODE}

\section{Populasi dan Sampel}

Populasi yang digunakan dalam penelitian ini adalah seluruh perusahaan sektor industri barang konsumsi yang terdaftar di Bursa Efek Indonesia (BEI) tahun 2016-2018. Sampel dalam penelitian ini dipilih dengan metode purposive sampling, dengan kriteria sebagai berikut: (1) Perusahaan sektor industri barang konsumsi yang terdaftar berturut-turut di Bursa Efek Indonesia (BEI) tahun 2016-2018; (2) Perusahaan sektor industri barang konsumsi yang mempublikasikan laporan keuangannya berturut-turut tahun 2016-2018; (3) Perusahaan sektor indusri barang konsumsi yang tidak mengalami kerugian dari tahun 2016-2018; (4) Perusahaan sektor indusri barang konsumsi yang membagikan dividen dari tahun 2016-2018; dan (5) Laporan keuangan menggunakan mata uang rupiah.

\section{Variabel dan Metode Analisis Variabel}

Variabel independen yang digunakan dalam penelitian ini adalah profitabilitas, lagged dividend, size, dan leverage. Variabel dependen dlam penelitian ini adalah kebijakan dividen.

\section{Metode Analisis}

Perhitungan Kebijakan Dividen

Menurut Sartono (2014), kebijakan dividen adalah keputusan apakah laba akan dibagikan kepada pemegang saham sebagai deviden atau ditahan dalam bentuk laba ditahan untuk pembiayaan investasi masa yang akan datang yang dapat diukur dengan Dividend Payout Ratio (DPR). DPR dapat dirumuskan sebagai berikut:

$$
D P R=\frac{\text { Dividend }}{\text { Laba bersih }}
$$

\section{Pengukuran Profitabilitas}

Pada penelitian ini rasio profitabilitas diukur menggunakan rasio return on assets (ROA). Nilai ROA yang tinggi merupakan sinyal positif bagi investor untuk memprediksi bahwa perusahaan dikemudian hari dalam kondisi yang menguntungkan. Hal ini selanjutnya akan meningkatkan daya tarik perusahaan kepada investor. ROA dapat dirumuskan sebagai berikut:

$$
\text { ROA }=\frac{\text { Laba Bersih Setelah Pajak }}{\text { Total Aset }}
$$

\section{Pengukuran Lagged Dividend}

Sejak penelitian awal tentang kebijakan dividen, penelitian telah membahas peran dividen masa lalu dalam menetapkan rasio pembayaran dividen saat ini. Dalam penelitian ini lagged dividend akan diukur dengan Dividen pershare tr-1 $_{\text {yang dirumuskan }}$ sebagai berikut:

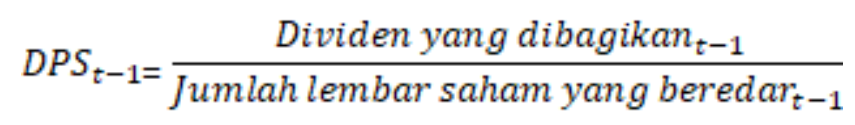

\section{Pengukuran Size}

Size atau ukuran perusahaan diukur dengan menggunakan logaritma dari total asset. Size yang merupakan besar kecilnya perusahaan dan diukur melalui besar kecilnya total aset yang dimiliki oleh perusahaan. Size dapat dirumuskan sebagai berikut:

\section{Size $=\operatorname{Ln}($ Total Aset $)$}

\section{Pengukuran Leverage}

Leverage digunakan untuk mengukur seberapa besar modal pemilik perusahaan dengan modal dari kreditur. Debt to Equity Ratio (DER) merupakan rasio yang digunakan untuk menilai hutang dengan ekuitas. DER dirumuskan sebagai berikut:

$$
\text { DER }=\frac{\text { Total Hutang }}{\text { Total Ekuitas }}
$$

\section{HASIL DAN PEMBAHASAN \\ Statistik Deskriptif dan Hasil Pengujian Asumsi Klasik}

Tabel 1. Hasil Uji Deskriptif

\begin{tabular}{lrrrrr}
\hline & N & Min & \multicolumn{1}{c}{ Max } & \multicolumn{1}{c}{ Mean } & \multicolumn{1}{c}{ Std. Dev } \\
\hline Profitabilitas & 57 & 0,028 & 0,527 & 0,140 & 0,121 \\
Lagged Dividend & 57 & 0,090 & 2600,119 & 296,178 & 590,682 \\
Size & 57 & 12,898 & 18,385 & 15,677 & 1,532 \\
Leverage & 57 & 0,164 & 2,683 & 0,820 & 0,696
\end{tabular}


Berdasarkan tabel 1 di atas dari hasil analisis statistik deskriptif menggambarkan deskripsi variabelvariabel. Variabel profitabilitas memiliki nilai minimum sebesar 0,028 dan nilai maksimum sebesar 0,527 dengan nilai rata-rata sebesar 0,140 . Sedangkan nilai standar deviasi sebesar 0,121 yang berarti bahwa penyebaran variabel profitabilitas pada kebijakan dividen adalah sebesar $12,1 \%$ dari 57 data penelitian yang diteliti. Variabel lagged dividend memiliki nilai minimum sebesar 0,090 dan nilai maksimum sebesar 2600,119 dengan nilai rata-rata sebesar 296,178. Sedangkan nilai standar deviasi sebesar 590,682 yang berarti bahwa penyebaran variabel lagged dividend pada kebijakan dividen adalah sebesar 59068,2\% dari 57 sdata penelitian yang diteliti. Variabel size memiliki nilai minimum sebesar 12,898 dan nilai maksimum sebesar 18,385 dengan nilai rata-rata sebesar 15,677. Sedangkan nilai standar deviasi sebesar 1,532 yang berarti bahwa penyebaran variabel size pada kebijakan dividen adalah sebesar 153,2\% dari 57 data penelitian yang diteliti. Variabel leverage memiliki nilai minimum sebesar 0,164 dan nilai maksimum sebesar 2,683 dengan nilai rata-rata sebesar 0,820. Sedangkan nilai standar deviasi sebesar 0,696 yang berarti bahwa penyebaran variabel leverage pada kebijakan dividen adalah sebesar $69,6 \%$ dari 57 data penelitian yang diteliti. Variabel kebijakan dividen memiliki nilai minimum sebesar 0,106 dan nilai maksimum sebesar 1,132 dengan nilai rata-rata sebesar 0,519. Sedangkan nilai standar deviasi sebesar 0,285 yang berarti bahwa penyebaran kebijakan dividen adalah sebesar $28,5 \%$ dari 57 data penelitian yang diteliti.

Uji asumsi klasik dilakukan agar uji regresi linear berganda dalam penelitian ini memiliki hasil yang signifikan dan representatif. Berdasarkan hasil uji asumsi klasik yang telah dilakukan menunjukan bahwa semua model regresi dalam penelitian ini memenuhi asumsi klasik.

Tabel 2. Hasil Uji Regresi Linier Berganda

\begin{tabular}{|c|c|c|c|}
\hline \multirow{2}{*}{ Model } & \multicolumn{2}{|c|}{ Unstandardized Coeficients } & \multirow[b]{2}{*}{ Beta } \\
\hline & $\mathbf{B}$ & Std. Error & \\
\hline (Constant) & 0,178 & 0,257 & \\
\hline Profitabilitas & 1,748 & 0,204 & 0,742 \\
\hline Lagged Dividend & 0,0001 & 0,0000 & 0,211 \\
\hline Size & 0,006 & 0,017 & 0,031 \\
\hline Leverage & $-0,031$ & 0,035 & $-0,077$ \\
\hline
\end{tabular}

Berdasarkan tabel 2 di atas hasil uji regresi linier beganda yaitu:

$$
\mathrm{Y}=0,178+1,748 \mathrm{ROA}+0,0001 \mathrm{DPS}_{t-1}+0,006 \mathrm{SIZE}-0,031 \mathrm{DER}
$$

Hasil dari analisis di atas, dapat diinterpretasikan sebagai berikut:

1. Konstanta sebesar 0,178 yang artinya apabila profitabilitas, lagged dividend, size, dan leverage sama dengan 0 (nol) atau ditiadakan, maka kebijakan dividen bernilai positif sebesar 0,178 satuan dengan asumsi variabel lain bernilai tetap.

2. Koefisien profitabilitas sebesar 1,748 menunjukkan bahwa setiap peningkatan profitabilitas sebesar 1 satuan maka akan diikuti oleh peningkatan kebijakan dividen sebesar 1,748 satuan.

3. Koefisien lagged dividend sebesar 0,0001 menunjukkan bahwa setiap peningkatan lagged dividend sebesar 1 satuan maka akan diikuti oleh peningkatan kebijakan dividen sebesar 0,0001 satuan.

4. Koefisien size sebesar 0,006 menunjukkan bahwa setiap peningkatan size sebesar 1 satuan maka akan diikuti oleh peningkatan kebijakan dividen sebesar 0,006 satuan.

5. Koefisien leveragesebesar $-0,031$ menunjukkan bahwa setiap penurunan leverage sebesar 1 satuan maka akan diikuti oleh penurunan kebijakan dividensebesar 0,031 satuan.

Tabel 3. Hasil Uji Kelayakan Modal (Uji F)

\begin{tabular}{ccccc}
\hline $\mathrm{F}_{\text {hitung }}$ & $\mathrm{F}_{\text {tabel }}$ & Sig. & Standar & Keterangan \\
\hline 23,676 & 2,55 & 0,000 & 0,05 & Model Layak \\
\hline
\end{tabular}

Berdasarkan tabel 3 di atas hasil uji kelayakan model Nilai $F_{\text {tabel }}$ diperoleh dari tabel statistik pada tingkat signifikansinya 0,05 dengan df1 (jumlah variabel-1)=4 dan df2 $=n-k-1=57-4-1=52$. Oleh karena itu, hasil yang diperoleh untuk $F_{\text {tabel }}$ sebesar 2,55. $F$ hitung $>F$ tabel dan tingkat signifikansi $<0.05$, maka Ho ditolak sehingga dapat disimpulkan bahwa terdapat pengaruh yang signifikan antara variabel independen dengan variabel dependen. 
Tabel 4. Hasil Uji Hipotesis (Uji t)

\begin{tabular}{lrllll}
\hline Hipotesis & \multicolumn{1}{c}{ thitung } & tabel $_{\text {taber }}$ & Sig. & Standar & Keterangan \\
\hline H1 & 8,582 & $>2,006$ & 0,000 & $<0,05$ & Diterima \\
H2 & 2,337 & $>2,006$ & 0,023 & $<0,05$ & Diterima \\
H3 & 0,348 & $<2,006$ & 0,729 & $>0,05$ & Ditolak \\
H4 & $-0,897$ & $<-2,006$ & 0,374 & $>0,05$ & Ditolak \\
\hline
\end{tabular}

\section{Hasil Pengujian Hipotesis}

Pengaruh Profitabilitas pada Kebijakan Dividen

Berdasarkan tabel 4 di atas, pengaruh profitabilitas pada kebijakan dividen menunjukkan hasil bahwa nilai thitung sebesar 8,582 dengan nilai signifikan 0,000 dan $\mathrm{t}_{\text {tabel }}$ sebesar 2,006 dengan taraf signifikannya $\alpha$ $=0,05$. Dari data tersebut menunjukkan bahwa $t_{\text {hitung }}>t_{\text {tabel }}(8,582>2,006)$ dengan nilai signifikan $0,000<0,05$. Maka H1 diterima dan Ho ditolak. Dengan demikian dinyatakan profitabilitas berpengaruh pada kebijakan dividen.

\section{Pengaruh Lagged Dividend pada Kebijakan Dividen}

Berdasarkan tabel 4 di atas, pengaruh lagged dividend pada kebijakan dividen menunjukkan hasil bahwa nilai $t_{\text {hitung }}$ sebesar 2,337 dengan nilai signifikan 0,023 dan tabel sebesar 2,006 dengan taraf signifikannya $\alpha$ $=0,05$. Dari data tersebut menunjukkan bahwa $t_{\text {hitung }}>t_{\text {tabel }} \quad(2,337>2,006)$ dengan nilai signifikan $0,023<0,05$. Maka H2 diterima dan Ho ditolak. Dengan demikian dinyatakan lagged dividend berpengaruh pada kebijakan dividen.

\section{Pengaruh Size pada Kebijakan Dividen}

Berdasarkan tabel 4 di atas, pengaruh size pada kebijakan dividen menunjukkan hasil bahwa nilai thitung sebesar 0,348 dengan nilai signifikan 0,729 dan $t_{\text {tabel }}$ sebesar 2,006 dengan taraf signifikannya $\alpha=0,05$. Dari data tersebut menunjukkan bahwa $t_{\text {hitung }}<t_{\text {tabel }}$ $(0,348<2,006)$ dengan nilai signifikan $0,729>0,05$. Maka H3 ditolak dan Ho diterima. Dengan demikian dinyatakan size tidak berpengaruh pada kebijakan dividen.

\section{Pengaruh Leverage pada Kebijakan Dividen}

Berdasarkan tabel 4 di atas, pengaruh leverage pada kebijakan dividen menunjukkan hasil bahwa nilai $t_{\text {hitung }}$ sebesar $-0,897$ dengan nilai signifikan 0,374 dan $t_{\text {tabel }}$ sebesar 2,006 dengan taraf signifikannya $\alpha=0,05$. Dari data tersebut menunjukkan bahwa $t_{\text {hitung }}<t_{\text {tabel }}$ ($0,897<-2,006)$ dengan nilai signifikan $0,374>0,05$. Maka H4 ditolak dan Ho diterima. Dengan demikian dinyatakan leverage tidak berpengaruh pada kebijakan dividen.

Tabel 5. Hasil Uji Koefisien Determinan

\begin{tabular}{ccccc}
\hline $\mathbf{R}$ & $\boldsymbol{R}$ Square & Adjusted $\boldsymbol{R}$ Square & Std. Error of the Estimate & Keterangan \\
\hline 0,803 & 0,646 & 0,618 & 0,175967 & $61,8 \%$ \\
\hline
\end{tabular}

Berdasarkan tabel 5 di atas determinasi (Adjusted $R^{2}$ )yaitu hasil perhitungan untuk nilai $\mathrm{R}^{2}$ diperoleh dalam analisis linear berganda dengan nilai Adjusted $R^{2}$ sebesar 0,618. Hal ini berarti bahwa persentase sumbangan pengaruh variabel profitabilitas, lagged dividend, size, dan leverage sebesar $61,8 \%$. Sedangkan sisanya yaitu $38,2 \%$ dijelaskan oleh variabel lain diluar variabel profitabilitas, lagged dividend, size, dan leverage.

\section{Diskusi Hasil Penelitian}

\section{Pengaruh Profitabilitas pada Kebijakan Dividen}

Berdasarkan tabel 4 menunjukkan bahwa variabel profitabilitas berpengaruh pada kebijakan dividen. Dividen adalah laba bersih yang diperoleh perusahaan. Laba yang diperoleh perusahaan digunakan untuk membayar dividen kepada investor.Jika laba yang diperoleh kecil, maka dividen yang akan dibagikan kecil, sebliknya jika laba yang diperoleh besar maka dividen yang dibagikan besar. Jadi, semakin besar kemampuan perusahaan dalam menghasilkan laba maka semakin besar dividen yang akan dibagikan kepada para investor. Sehingga dapat dinyatakan bahwa profitabilitas dapat mempengaruhi kebijakan dividen, karena kebijakan dividen berkaitan dengan perolehan tingkat laba yang akan dibagi sebagai dividen berdasarkan ketersediaan kas laba. Oleh karena itu profitabilitas berpengaruh pada kebijakan dividen. Hasil penelitian ini sejalan dengan penelitian Pasadena (2013) bahwa profitabilitas berpengaruh terhadap kebijakan dividen. Namun berdeda dengan penelitian Sari dan Sudjarni (2015) bahwa profitabilitas tidak berpengaruh terhadap kebijakan diividen.

\section{Pengaruh Lagged Dividend pada Kebijakan Dividen}

Berdasarkan tabel 4 menunjukkan bahwa variabel lagged dividend berpengaruh pada kebijakan dividen. Dalam hal ini maka dividen dikatakan stabil. Agar dividen stabil maka perusahaan sebelum membagikan dividen tahun berjalan harus melihat kebijakan dividen tahun sebelumnya. Investor akan melihat kestabilan perusahaan dalam membagikan dividen sebelum mereka berinvestasi. Investor memperhatikan informasi pembagian dividen sebagai berita yang bagus atau buruk, sehingga manager akan menghindari sinyal negatif pasar mengenai prospek perusahaan di masa depan. Jika pendapatan perusahaan menurun, dividen tidak diturunkan maka pasar akan lebih percaya pada 
saham perusahaan, dibandingkan perusahaan yang menurunkan dividen ketika pendapan menurun. Dengan membagikan dividen secara stabil, dapat dinyatakan dalam jangka panjang perusahaan akan menjadi lebih baik dari kondisi pada saat terjadi penurunan. Agar dividen mengikuti kebijakan dividen stabil, maka kebijakan dividen tahun berjalan harus mempertimbangkan dividen tahun sebelumnya. Oleh karena itu lagged dividend berpengaruh pada kebijakan dividen. Hasil penelitian ini sejalan dengan penelitian Pouheydari (2009), bahwa pembayaran dividen masa lalu, lagged dividend memengaruhi kebijakan dividen saat ini. Namun berdeda dengan penelitian Jabbouri (2016), menunjukkan tidak ada hubungan dividen tahun lalu dengan kebijakan dividen.

\section{Pengaruh Size pada Kebijakan Dividen}

Berdasarkan tabel 4 menunjukkan bahwa variabel size tidak berpengaruh pada kebijakan dividen. Besar kecilnya total aset tidak menjamin perusahaan mempunyai akses yang mudah ke pasar modal dan perusahaan dengan total aset yang tinggi tidak menjamin bahwa rasio pembayaran dividen akan tinggi, sebaliknya perusahaan dengan nilai total aset yang rendah belum tentu membagikan dividen dengan jumlah yang rendah.Perusahaan yang mempunyai size besar mempunyai kecenderungan membayar dividen rendah, hal ini untuk mengurangi ketergantungan perusahaan pada pendanaan investasi secara eksternal, karena bagi perusahaan pendanaan eksternal itu terlalu mahal sehingga perusahaan lebih mengutamakan dari pendanaan internal. Oleh karena itu size tidak berpengaruh pada kebijakan dividen. Hasil penelitian ini sejalan dengan penelitian Rosmawati (2019) bahwa size tidak berpengaruh terhadap kebijakan dividen. Namun berdeda dengan penelitian Audita dan Achsim (2014) bahwa size berpengaruh terhadap kebijakan dividen.

\section{Pengaruh Leverage pada Kebijakan Dividen}

Berdasarkan tabel 4 menunjukkan bahwa variabel leverage tidak berpengaruh pada kebijakan dividen. Berdasarkan pecking order theory, perusahaan lebih mengutamakan dana internal daripada dana eksternal dalam aktivitas pendanaan. Dana eksternal dibutuhkan apabila dana internal tidak mencukupi, dilihat dari besarnya laba, laba ditahan, atau arus kas. Dana eksternal yang lebih diutamakan perusahaan adalah utang. Dalam hal ini leverage tidak berpengaruh terhadap kebijakan dividen disebabkan adanya tekanan dari para investor kepada manajer untuk tetap membagikan dividen walaupun dalam keadaan utang tinggi maupun rendah. Dibagikannya dividen kepada para investor bertujuan untuk menjaga reputasai perusahaan agar perusahaan tetap baik dimata para investor. Oleh karena itu leverage tidak berpengaruh pada kebijakan dividen. Hasil penelitian ini sejalan dengan penelitian Apriliani dan Natalylova (2017) bahwa leverage tidak memiliki pengaruh terhadap kebijakan dividen. Namun berdeda dengan penelitian Nurchaqiqi dan Suryarini (2018) bahwa variabel leverage dinyatakan berpengaruh terhadap kebijakan dividen pada penelitian.

\section{SIMPULAN}

Penelitian ini bertujuan untuk menguji dan menganlisis pengaruh profitabilitas, lagged dividend, size, dan leverage pada kebijakan dividen. Variabel independen dalam penelitian ini adalah profitabilitas, lagged dividend, size, dan leverage. Variabel dependen dalam penelitian ini adalah kebijakan dividen yang diukur dengan Dividen Payout Ratio (DPR). Populasi dalam penelitiann ini adalah perusahaan sektor industri barang konsumsi yang terdaftar di Bursa Efek Indonesia (BEI) tahun 2016-2018 . Jenis penelitian ini adalah penelitian kuantitatif. Pengambilan sampel dengan teknik purposive sampling menghasilkan 19 perusahaan sektor industri barang konsumsi tahun 2016-2018 sesuai kriteria yang ditentukan, sehingga diperoleh 57 data penelitian. Penelitian ini menggunakan analisis regresi linear berganda dengan program IMB SPSS versi 23 . Berdasarkan hasil penelitian ini diindikasikan bahwa:

1. Profitabilitas berpengaruh pada kebijakan dividen. Hal ini karena semakin besar kemampuan perusahaan dalam memperoleh laba maka pembagian dividen semakin besar, sebaliknya jika laba yang diperoleh kecil maka dividen yang dibagikan kecil, karena pembagian dividen berdasarkan laba yang diperoleh perusahaan.

2. Lagged dividend berpengaruh pada kebijakan dividen. Hal ini karena investor akan melihat kestabilan perusahaan dalam membagikan dividen sebelum berinvestasi. Agar pembagian dividen stabil, maka perusahaan perlu melihat pembagian dividen tahun sebelumnya sebelum menentukan kebijakan dividen tahun berjalan agar tidak terjadi penurunan pembagian dividen yang dapat penyebabkan dampak negatif bagi perusahaan.

3. Size tidak berpengaruh pada kebijakan dividen. Hal ini karena besar kecilnya total aset tidak menjamin perusahaan mempunyai akses yang mudah ke pasar modal. Perusahaan dengan total aset tinggi belum tentu membagikan dividen tingggi, sebaliknya perusahaan dengan total aset rendah belum tentu membagikan dividen rendah. Perusahaan dengan total aset tinggi cenderung membagikan dividen rendah bertujuan untuk mengurangi ketergantungan pendanaan eksternal.

4. Leverage tidak berpengeruh pada kebijakan dividen. Hal ini karena adanya tekanan dari para investor untuk tetap membagikan dividen walaupun perusahaan dalam keadaan utang tinggi maupun rendah. Dibagikannya dividen ini untuk menjaga reputasai perusahaan di mata para investor. 


\section{DAFTAR PUSTAKA}

Apriliani, A., dan Natalylova, K. (2017). Faktor-faktor yang Memepengaruhi Kebijakan Dividen pada Perusahaan Manufaktur di BEI. Jurnal Bisnis dan Akuntansi, Vol.19(1a): 49-57.

Audita, I. G., dan Achsim, M. (2014). Pengaruh Agency Cost terhadap Kebijakan Dividen. Jurnal Apliaksi Manajemen, Vol.12(2): 284-294.

Benlemlih, M. (2018). Corporate Social Responsibility and Dividend. Research in International Business and Finance, Vol.47: 114-138.

Brigham, dan Houston. (2014). Dasar-dasar Manajemen Keuangan, Edisi 11. Jakarta: Salemba Empat.

Damayanti, R., Marwati, F. S., dan Widayanti, R. (2017). Analisa Kebijakan Dividen Berdasarkan Teori Lintner. Jurnal Ekonomi dan Bisnis, Vol.1(2): 183-194.

Dewi, I. A., dan Sedana, I. B. (2018). Faktor-faktor yang Mempengaruhi Kebijakan Dividen pada Perusahaan Manufaktur di BEI. E-Jurnal Manajemen Unud, Vol.7(7): 3623-3652.

Dhuhri, R., dan Diantimala, Y. (2018). The Influence of Institutional Ownership, Individual Ownership, and Managerial Ownership Toword Dividend Payout Ratio at Non-Financial Companies Registered in Indonesia Stock Exchange in 20122016. International Journal of Social Science and Economic, Vol.3(3): 786-801.

Fahmi, I. (2011). Analisis Laporan Keuangan. Bandung: Alfabeta.

Hakim, I. (2011). Analisis Faktor-faktor yang Mempengaruhi Kebijakan Dividen Studi pada Perusahaan Manufaktur yang terdaftar di BEI. Undip Semarang.

Jabbouri, I. (2016). Determinants of Corporate Dividend Policy in Emerging Markets: Evidance from MENA Stock Markets . Research in International Business and Finance, Vol.37: 283-298.

Kasmir. (2016). Analisis Laporan Keuangan, Cetakan Ketiga. Jakarta: PT Raja Grafindo Persada.

Lintner, J. (1956). Distribution of Incomes of Corporations Among Dividens, Retained Earning, and taxes. American Economic Review, Vol.46(2): 97-113.

Madyoningrum, A. W. (2019). Pengaruh Firm Size, Leverage, dan Profitabilitas terhadap Kebijakan Dividen. Jurnal Bisnis dan Manajemen Universitas Merdeka Malang, Vol.6(1): 45-55.

Marlina, L., dan Danica, C. (2009). Analisis Pengaruh Cash Position, Debt to Equity Ratio, dan Return of Assets terhadap Kebijakan Dividen Payout Ratio . Jurnal Manajemen Bisnis, Vol.2(1): 1-6.

Martini et al. (2014). Akuntansi Keuangan Menengah Berbasis PSAK. Jakarta: Salemba Empat.

Munawir, S. (2010). Analisis Laporan Keuangan, Edisi Keempat. Yogyakarta: BPFE.
Nurchaqiqi, R., dan Suryarini, T. (2018). The Effect of Leverage and Liquidity on Cash Dividend Policy with Profitability as Moderator Moderating. Accounting Analysis Journal, Vol.7(1): 10-16.

Parica et al. (2013). Pengaruh Laba Bersih, Arus Kas Operasi, Likuiditas, dan Profitabilitas terhadap Kebijakan Dividen pada Perusahaan Automotive and AlliedProduct yang terdaftar di BEI. Jurnal Akuntansi Universitas Riau, Vol.2(1).

Parsian, H., dan Shams, A. K. (2013). A study on the effect of free cash flow and Profitability Current Ratio on Dividend Payout Ratio: Evidence from Tehran Stock Exchange. Management Science Letters, Vol.4: 63-70.

Pasadena, R. P. (2013). Pengaruh Likuiditas, Leverage, Profitabilitas dan Ukuran Perusahaan terhadap Kebijakan Dividen pada Perusahaan Manufaktur yang terdaftar di BEI.

Pouheydari, D. (2009). A survey of management views on dividend policy in Iranian firms. Inter Islamic Middle Eastren Financ Manag, Vol.2(1): 20-31.

Ramadhani, S., Andreas, dan Desmiyawati. (2015). Pengaruh Corporate Governance Perception Index dan Kebijakan Hutang terhadap Nilai Perusahaan dengan Kebijakan Dividen sebagai Variabel Intervening. Jurnal Akuntansi.

Rehman, A., dan Takumi, A. (2012). Journal Determinants of Dividend Payout Ratio: Evidence from Karachi Stock Exchange. Vol.1(1): 20-27.

Riastini, N. A., dan Pradnyani, N. P. (2017). Pengaruh Rasio Keuangan Terhadap Kebijakan Dividen pada Perusahaan Manufaktur yang terdaftar dalam Indeks LQ45 di BEI tahun 2011-2015. Vol.13(1): 197-205.

Riyanto, B. (2008). Dasar-dasar Pembelanjaan Perusahaan. Yogyakarta: Penerbit GPEE.

Rosmawati, W. (2019). Pengaruh Rasio Likuiditas dan Solvabilitas terhadap Kebijakan Dividen Perusahaan Non Jasa Keuangan di BEI Jakarta. Jurnal Ekonomi, Vol.21(2): 154-166.

Sari, K. A., dan Sudjarni, L. K. (2015). Pengaruh Likuiditas, Leverage, Pertumbuhan Perusahaan, dan Profitabilitas terhadap Kebijakan Dividen pada Perusahaan Manufaktur di BEI. E-Jurnal Manajemen Unud, Vol.4(10): 3346-3374.

Sartono. (2014). Manajemen Keuangan Teori dan Aplikasi. Yogyakarta: BPFE.

Seftianne, dan Handayani. (2011). Faktor-faktor yang Mempengaruhi Struktur Modal pada Perusahaan Publik Sektor Manufaktur. Jurnal Bisnis dan Akuntansi, Vol.13(1).

Shaheen, R., dan Ullah, S. (2018). Effect of International and Insider Ownership on Dividend Policy. Journal of Business and Tourism, Vol.4(2).

Silaban, D. P., dan Purnawati, N. K. (2016). Pengaruh Profitabilitas, Struktur Kepemilikan, Tingkat Pertumbuhan, dan Efektifitas Usaha terhadap 
Kebijakan Dividen di Perusahaan Manufaktur. EJurnal Manajemen Unud, Vol.5(2): 1251-1281.

Thirtayatra, I. M., dan Arliando, L. (2008, April 1). Kebijakan Dividen Warta Bapepam-LK, Edisi Juli 2008. Diambil kembali dari http://www.bapepam.go.id/pasar_modal/publikasi _pm/info_pm/warta/warta.html: 2016

Welas, dan Nugroho, S. Y. (2019). Analisis Faktorfaktor yang Mempengaruhi Kebijakan Dividen. Jurnal Riset Akuntansi dan Keuangan, Vol.1(1): 43-54.

Wiagustini, L. P. (2014). Dasar-dasar Manajemen Keuangan. Denpasar: Udayana University Press.

Widyawati, D., dan Indriani, A. (2019). Determinants of Dividend Payout Ratio: Evidance from Indonesian Manufacturing Companies. International Journal of Business, Vol.2(2). 